\title{
Energy Recovery Potential in Industrial and Municipal Wastewater Networks Using Micro-Hydropower in Spain
}

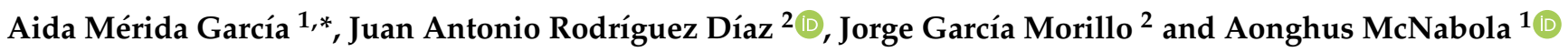 \\ 1 Department of Civil, Structural and Environmental Engineering, Trinity College Dublin, \\ Dublin D02 PN40, Ireland; amcnabol@tcd.ie \\ 2 Department of Agronomy, Campus Rabanales, University of Cordoba, Edif. Da Vinci, 14071 Cordoba, Spain; \\ jarodriguez@uco.es (J.A.R.D.); g62gamoj@uco.es (J.G.M.) \\ * Correspondence: g82megaa@uco.es
}

Citation: Mérida García, A.;

Rodríguez Díaz, J.A.; García Morillo,

J.; McNabola, A. Energy Recovery

Potential in Industrial and Municipal Wastewater Networks Using Micro-Hydropower in Spain. Water 2021, 13, 691. https://doi.org/ 10.3390/w13050691

Academic Editor: Giuseppe Mancini

Received: 8 February 2021

Accepted: 28 February 2021

Published: 4 March 2021

Publisher's Note: MDPI stays neutral with regard to jurisdictional claims in published maps and institutional affiliations.

Copyright: (c) 2021 by the authors. Licensee MDPI, Basel, Switzerland. This article is an open access article distributed under the terms and conditions of the Creative Commons Attribution (CC BY) license (https:// creativecommons.org/licenses/by/ $4.0 /)$.

\begin{abstract}
The use of micro-hydropower (MHP) for energy recovery in water distribution networks is becoming increasingly widespread. The incorporation of this technology, which offers low-cost solutions, allows for the reduction of greenhouse gas emissions linked to energy consumption. In this work, the MHP energy recovery potential in Spain from all available wastewater discharges, both municipal and private industrial, was assessed, based on discharge licenses. From a total of 16,778 licenses, less than $1 \%$ of the sites presented an MHP potential higher than $2 \mathrm{~kW}$, with a total power potential between 3.31 and 3.54 MW. This total was distributed between industry, fish farms and municipal wastewater treatment plants following the proportion $51-54 \%, 14-13 \%$ and $35-33 \%$, respectively. The total energy production estimated reached $29 \mathrm{GWh} \cdot$ year $^{-1}$, from which $80 \%$ corresponded to sites with power potential over $15 \mathrm{~kW}$. Energy-related industries, not included in previous investigations, amounted to $45 \%$ of the total energy potential for Spain, a finding which could greatly influence MHP potential estimates across the world. The estimated energy production represented a potential $\mathrm{CO}_{2}$ emission savings of around 11 thousand tonnes, with a corresponding reduction between $\mathrm{M} € 2.11$ and $\mathrm{M} € 4.24$ in the total energy consumption in the country.
\end{abstract}

Keywords: wastewater treatment plants; industries; fish farms; renewable energy; hydropower potential

\section{Introduction}

The increase in global energy consumption [1] has been transformed into a rise in fossil fuel demand, led by natural gas, representing $44 \%$ of the global annual primary energy demand [2]. This growth is driven by an economy with increasing energy requirements due to the technological revolution and, above all, the demand for cooling, heating and transport. In this context, global energy-related $\mathrm{CO}_{2}$ emissions grew by $1.7 \%$ in 2018 to reach a historic high of 33.1 annual $\mathrm{Gt} \mathrm{CO}_{2}$, which represents an increase of around $0.5 \%$ for every $1 \%$ growth in global economic output, despite the growth of renewable energies [2]. These figures support the unquestionable need of a global transformation of the energy generation system.

The increase in water and energy consumption in industry coincides with fast development transforming water use patterns in emerging market economies. The use of water by sectors is clearly led by the primary sectors (agriculture, forestry, fishing, aquaculture, mining and quarrying, among others), while industry (self-supply) and municipal water supply represents around $8 \%$ of total water use [3]. The industrial productivity of course varies between products, but also, for the same product, it varies significantly across countries $[4,5]$. For that reason, it is not easy to estimate real values of water consumption in industries, nor is it easy to access to real data for specific products. On the other hand, energy requirements related to the industry sector reached 261 million tonnes 
of oil equivalent in Europe, only behind the transport sector (326.9 Mt oil eq.), and consumption in households (288 Mt oil eq.) [6]. In Spain, industry has traditionally been the largest consumer of energy. However, savings and efficiency measures that began to be implemented in the 1970s and process improvements by the use of new technologies have resulted in transport exceeding industry's energy consumption [7]. The energy demand for extraction, supply and distribution of water, as well as water treatments in the urban sector implies a large amount of energy requirements [8]. This energy is partly wasted, as overpressure and leakages are generated in specific locations of the water distribution networks $[9,10]$. Energy recovery through micro-hydropower (MHP) not only addresses the reduction of energy consumption in water distribution networks, as it also explores the improvement of efficiency and sustainability in the water industry $[1,11]$. For that reason, the study of the potential of energy recovery using MHP in water distribution networks [12-14], break pressure tanks [15], or at the end of the network of a wastewater treatment plant (WWTP) [16,17], has been already addressed in several works. In the case of Gallagher et al. [13], the developed methodology was focused on assessing the potential energy recovery sites in the water and WWTP infrastructure in the UK and Ireland, showing estimations of around 17.9 GWh per annum of potential energy generation with MHP. The variability on the flow and, thus, on the turbine efficiency, has been explored to define the applicability of this technology on a small scale in WWTPs [12]. MHP technology has also already been applied to irrigation networks [18,19], assessing the potential for energy recovery in the irrigation sector and carbon savings, which for the case of the Bembezar Margen Izquierda Irrigation District (south Spain), it was estimated as $270.5 \mathrm{MWh}$ and $108 \mathrm{t} \mathrm{CO}_{2}$ eq., respectively [20]. The use of Pumps As Turbines (PAT) has proven to be a viable and cost-effective technical solution for this energy recovery practice in water distribution networks $[1,21]$, which has also increased the interest in this technology even for developing countries [22]. Nevertheless, the optimal location and selection of the turbine or PAT can significantly impact on the energy production and economic savings [23]. This high interest on MHP and energy recovery, from the economic and environmental points of view, is challenged by the difficulty of creating a universal methodology applicable to any area and country to assess its potential impact. Bousquet et al. [24] assessed the potential for energy recovery using MHP turbines across all municipal WWTPs in Switzerland, finding 19 sites with a total MHP potential for energy production of $9.3 \mathrm{GWh} \cdot \mathrm{year}^{-1}$. However previous investigations have neglected to include in their assessment of this potential all forms of wastewater discharges including private industrial WWTPs associated with, for example, food processing or other water-intensive products.

The objective of this work was to investigate the research question-what is the potential for hydraulic energy recovery in private water-intensive industrial discharges using micro-hydropower? In order to evaluate this MHP energy recovery potential in Spain including all wastewater discharges, both municipal and private industrial were assessed. Assessing all discharge types enabled a comparison of their relative importance. This was included in three broad categories of fish farms, municipal WWTPs, and other private industrial sectors. Fish farms were separated from private industry as a sole category in this case, as they represented a large share of industrial discharges in Spain. The established methodology was focused on expanding the possibilities of MHP development for the municipal and industrial wastewater sectors, evaluating the potential energy savings and helping reduce their environmental impacts through the adoption of renewable energies. This methodology was based on the available water volumes from the discharge licenses to estimate the potential of energy generation by the installation of a micro-turbine or PAT. The data were collected from the water authorities responsible for the water management in the main river basin in the country. 


\section{Methodology}

\subsection{Study Area}

The study area was focused on the main seven river basins in Spain (Figure 1) for which the information about the water discharge licenses was publicly available. The study covered a total area of $394,571 \mathrm{~km}^{2}$, representing $78 \%$ of the country total area and $80 \%$ of the peninsular Spanish area. The sum of the annual discharge volumes reaches around $4976 \mathrm{Hm}^{3}$, which correspond to 16,778 different discharge licenses. Most discharge licenses could be classified into three general groups, depending on the provenance of the effluent, corresponding to WWTPs, industry and fish farms. Within industry, some further subgroups were then distinguished, which will be specified later. These river basins included Duero, Ebro, Tajo, Jucar, Guadiana, Guadalquivir and Segura rivers, for which the total area, population, total authorized discharge volume and number of licenses are summarized in Table 1.

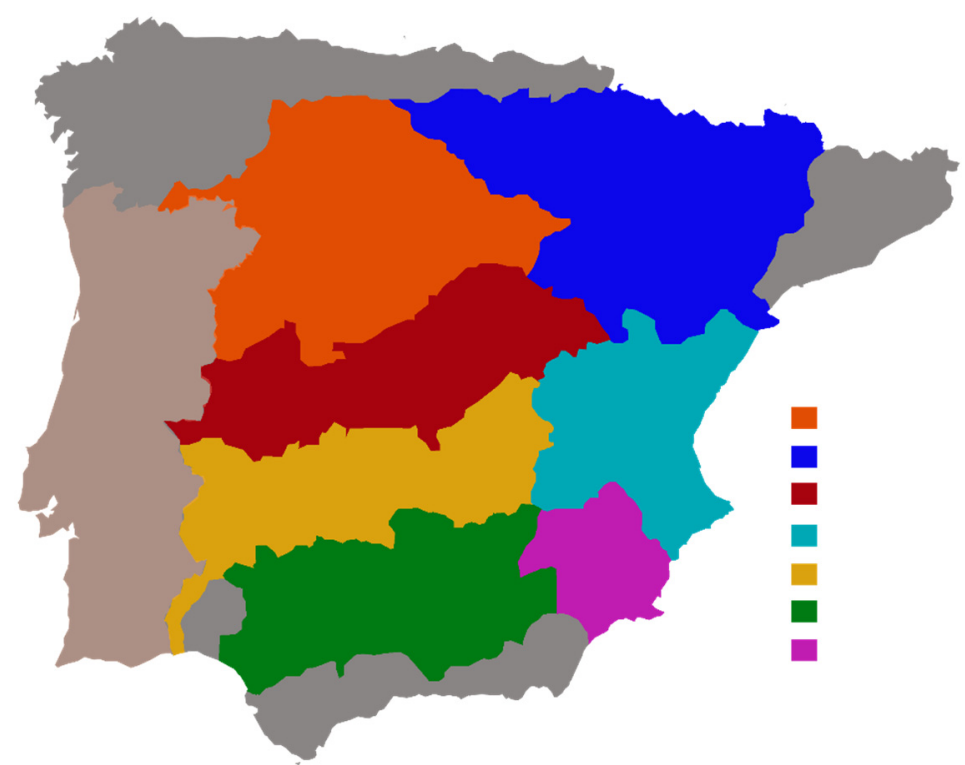

Duero

Ebro

Tajo

Jucar

Guadiana

Guadalquivir

Segura

Figure 1. Area corresponding to the river basins analysed in Spain for the estimation of the energy recovery potential with micro-hydropower (MHP) in wastewater treatment plants (WWTPs), industry and fish farms.

Table 1. Total area, population, authorized discharge volume and number of discharge licenses for the different river basins are analysed.

\begin{tabular}{|c|c|c|c|c|}
\hline River Basin & $\begin{array}{c}\text { Area } \\
\left(\mathrm{km}^{2}\right)\end{array}$ & $\begin{array}{l}\text { Population } \\
\left(\times 10^{6}\right)\end{array}$ & $\begin{array}{c}\text { Authorised Volume } \\
\left(\mathrm{Hm}^{3}\right)\end{array}$ & Total Licenses \\
\hline Duero & 78,458 & 2.2 & 861 & 5816 \\
\hline Ebro & 85,534 & 3.2 & 1268 & 4283 \\
\hline Tajo & 55,781 & 7.9 & 1755 & 1844 \\
\hline Jucar & 42,735 & 5.0 & 345 & 1949 \\
\hline Guadiana & 55,513 & 1.5 & 105 & 565 \\
\hline Guadalquivir & 57,525 & 4.1 & 562 & 1637 \\
\hline Segura & 19,025 & 2.0 & 81 & 684 \\
\hline
\end{tabular}

\subsection{Potential Energy Recovery Sites Database}

Due to no detailed data being available about discharge flows from industrial water users in the different river basins, the information corresponding to their discharge license, from the public domain, was considered the most accurate way to assess the MHP energy recovery potential on a broad level. The discharge licenses included the name of the factory/user, the maximum authorised annual discharge volume and the discharge outfall 
location (UTM-Universal Transverse Mercator coordinates) (Figure 2). From the UTM coordinates, it was possible to determine the elevation for the discharge points, using digital elevation models, while for the point of generation/exit of the effluent, the elevation was also obtained from digital elevation models corresponding to the location of each factory, fish farm or WWTP. This work had to be conducted on a case-by-case basis as no information about the geographic location of the factory/WWTP/fish farm was available on the water discharge licenses databases. Once both elevations were known, the available dynamic height $\left(\mathrm{H}_{\mathrm{ava}}\right)$ was determined as the difference between them. To carry out this analysis in an effective and time-efficient manner, a sub-selection of the total number of discharge authorisations $(16,778)$ in the database was set. Conducting the head assessment for all 16,788 discharge licenses on a case-by-case basis would have been excessively laborious. In addition, this was deemed unnecessary as the flow rates corresponding to some of the discharge licenses were found to be too small to have significant MHP potential, considering the likely head drops available.

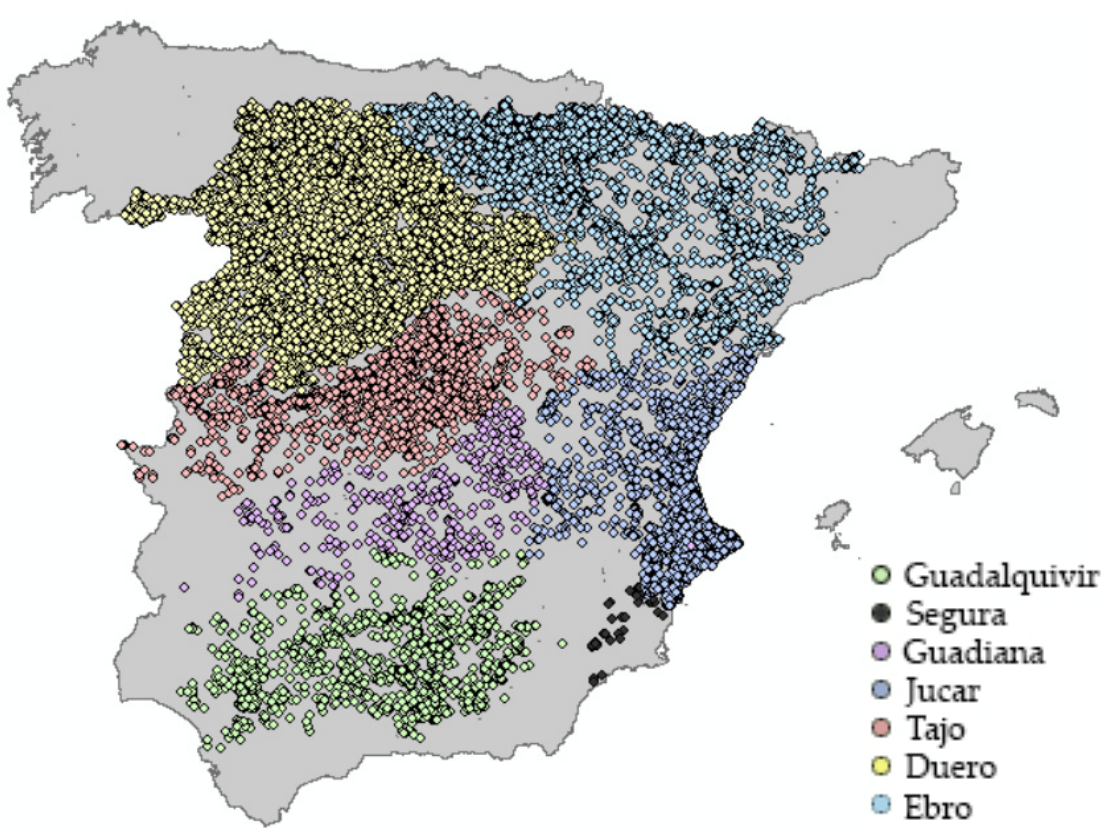

Figure 2. Water discharge points location from the licenses in the selected river basins in Spain.

The site pre-selection was made by establishing $2 \mathrm{~kW}$ as minimum economically viable power for an energy recovery installation using MHP in these setting. This minimum power was based on previous studies, which indicated that smaller turbine sizes were found to be unprofitable [25]. Thus, from the individual annual water discharge volume from licences, the annual average flow was estimated, assuming 365 days.year ${ }^{-1}$ and $24 \mathrm{~h} \cdot$ day $^{-1}$ of operation, as the most pessimistic scenario from the point of view of the volume distribution in available flow. Once flow values were estimated, the minimum required dynamic height $\left(H_{\min }\right)$ for a $2 \mathrm{~kW}-\mathrm{MHP}$ installation was determined, following Equation (1):

$$
P=\rho \cdot g \cdot Q \cdot H_{\min } \cdot e_{0}
$$

where $P$ is the power, set at $2 \mathrm{~kW}, \rho$ is the water density $\left(\mathrm{kg} \cdot \mathrm{m}^{-3}\right), g$ is the gravity acceleration $\left(\mathrm{m}^{2} \cdot \mathrm{s}^{-1}\right), Q$ is the flow $\left(\mathrm{m}^{3} \cdot \mathrm{s}^{-1}\right), H_{\min }$ the minimum required dynamic height (m) and $e_{0}$ the overall estimated efficiency for the installation. In this case, an average value for the efficiency was assumed (0.60), based on previous works as a conservative estimate $[8,13,20]$.

After the $H_{\min }$ requirements calculations, only the set of cases whose $H_{\min }$ was equal or lower than $15 \mathrm{~m}$ was selected to look for the sites with energy recovery potential for MHP. This limit value was set as a conservative threshold after it was found that very 
few cases met the requirement of having a difference in height between the wastewater treatment works and the discharge point higher than 10-12 $\mathrm{m}$.

\subsection{Power Estimations and Energy Recovery Potential Assessment}

Once the possible sites were identified and selected, their $H_{\min }$ values were compared with the corresponding available dynamic height $\left(\mathrm{H}_{\mathrm{ava}}\right)$ for each particular site, measured using digital elevation models. Those sites in which $\mathrm{H}_{\text {ava }}$ was equal or higher than $H_{\text {min }}$ conformed to the group of sites with MHP potential. The power potential was calculated using Equation (1), considering again an overall efficiency for the installation of 0.60. After the power estimations, the potential annual energy recovery for the different sites was then calculated. In this case, annual average flows were considered, and 365 days.year ${ }^{-1}$ and $24 \mathrm{~h} \cdot$ day $^{-1}$ were fixed again as the working time for factories, WWTPs and fish farms, as a conservative hypothesis.

A schematic representation of the main steps of all the process is defined in Figure 3.

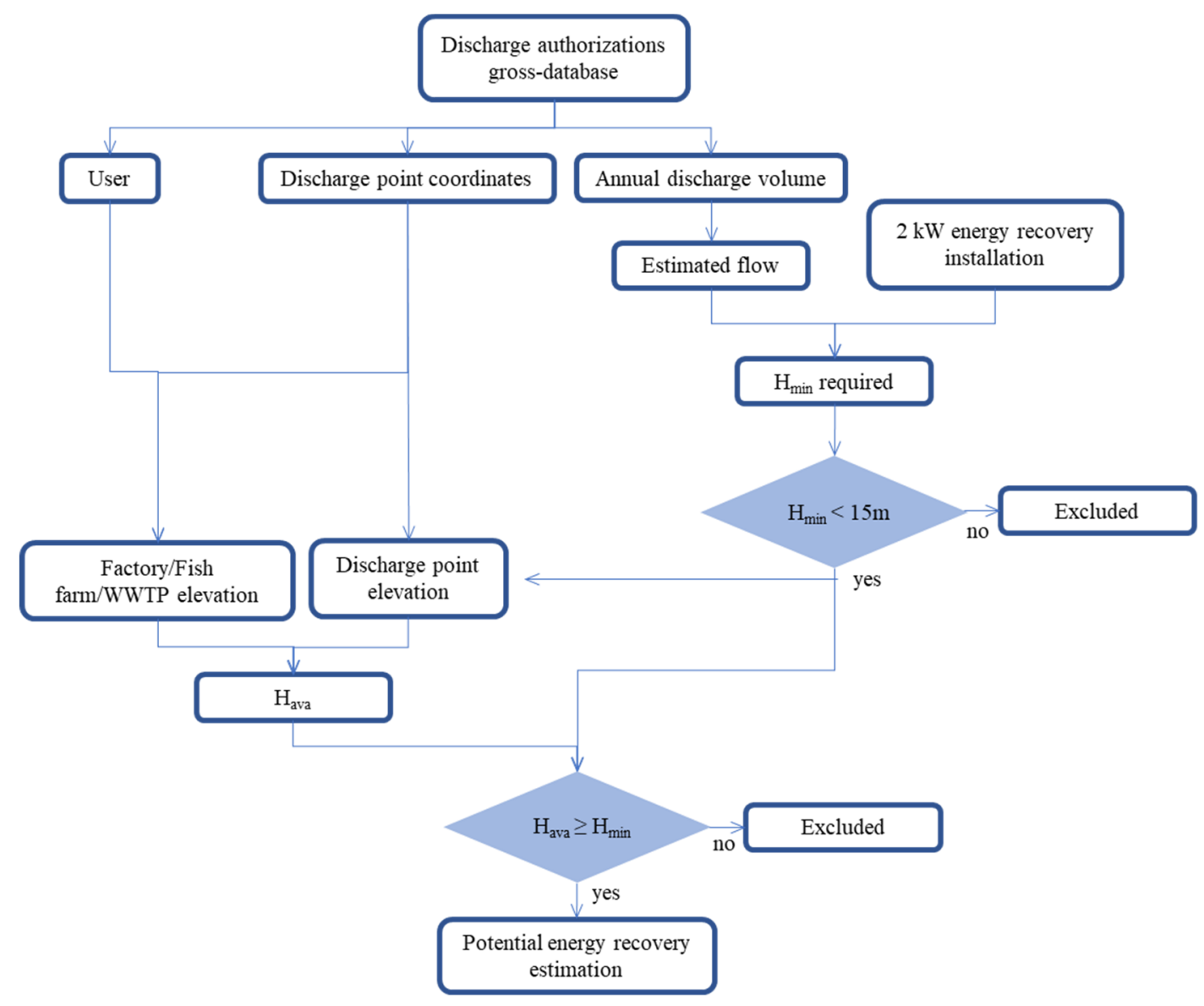

Figure 3. Schematic representation of the process stablished to determine the energy recovery potential with MHP from discharge licenses data.

\subsection{Economical and Greenhouse Gas Emissions Savings Projection}

After identifying the possible sites with energy recovery potential with MHP, as well as estimating the power and energy that would be generated at these sites, a comparison between this energy production and the total energy consumed at a country scale was made. Then, the corresponding economic savings, considering an average price for electricity from the grid in Spain, was also estimated. Likewise, the positive impact on the environmental aspects that the use of this recovered energy would generate was also evaluated. This was made by estimating the amount of greenhouse gas emissions corresponding to the 
total potential energy generated with MHP. For this purpose, an average ratio for Spain of equivalent $\mathrm{CO}_{2}$ emissions per unit of electricity consumed was used.

\subsection{Sensitivity Analysis}

Once the evaluation of the potential for energy recovery with MHP in Spain was completed, under the previously established criteria, a complementary analysis was carried out. This complementary analysis considered a daily operating time of $12 \mathrm{~h}$, instead of $24 \mathrm{~h}$. This new criterion would theoretically increase the number of potential sites, as the same water discharge volume is distributed over a shorter operating time, providing a higher flow and therefore, a higher MHP potential.

\section{Results and Discussion}

\subsection{Potential Energy Recovery Sites Database}

The initial database included a total of 16,778 discharge licenses, corresponding to the seven river basins analysed, for which the individual area was previously detailed in Table 2. From this total, sites which required less than $15 \mathrm{~m}$ as difference in height, between the discharge point and the effluent emission point to produce a potential $2 \mathrm{~kW}$ MHP installation, were listed in the so-called 'test set', making up a total of 471 sites. Those sites presented annual discharge volumes in the range 0.62 to $210 \mathrm{Hm}^{3}$, which represents flow values between 0.02 and $24 \mathrm{~m}^{3} \cdot \mathrm{s}^{-1}$. Under these established restrictions, no potential sites were found for the Segura River basin, for which $H_{\min }$ values were too high due to low annual volumes, so the total of 471 sites of the test set belonged to the remaining river basins, with the following distribution-16\% Duero, $28 \%$ Ebro, $13 \%$ Guadalquivir, $3 \%$ Guadiana, $15 \%$ Jucar, and 25\% Tajo. The representation of the three main categories in this test set was $18 \%, 9 \%$ and $73 \%$ for industry, fish farms and Municipal WWTPs, respectively. Nevertheless, while the number of sites for the Municipal WWTPs group showed a significative majority, in terms of annual discharge volumes, the distribution between the categories did not show the same differences, with 30-31\% of the total volume for both industry and fish farms and 39\% for Municipal WWTPs. In this way, the Tajo and Ebro river basins represented more than half of the total annual discharge volume, with $39 \%$ and $27 \%$, respectively. However, when studying the population corresponding to each of the basins, it was observed that although the Tajo river basin is one of the most populated, with $7.9 \mathrm{M}$ people, this does not apply to the Ebro basin. Thus, while Tajo presented 98 possible sites in the Municipal WWTPs group and 19 for the industry category, the Ebro reduced the Municipal WWTPs to 77 but doubled the possible sites for industry. These figures show that a priori, an important contribution to the energy recovery potential at a river basin level could come not only from the WWTPs, but also from the industry sector.

Table 2. Distribution of the number of sites with potential for MHP in the different river basins and categories.

\begin{tabular}{cccccc}
\hline & Basin Total & Industry & Fish Farms & WWTP & $\begin{array}{c}\text { Corresponding Volume } \\
\left(\mathbf{H m}^{\mathbf{3}} \mathbf{)}\right.\end{array}$ \\
\hline Duero & 20 & 6 & 5 & 9 & 164 \\
Ebro & 52 & 19 & 14 & 19 & 937 \\
Guadalquivir & 14 & 4 & 0 & 10 & 298 \\
Guadiana & 1 & 0 & 0 & 1 & 6 \\
Jucar & 21 & 1 & 3 & 17 & 173 \\
Segura & 0 & 0 & 0 & 0 & 0 \\
Tajo & 46 & 5 & 2 & 39 & 1562 \\
Total & 154 & 35 & 24 & 95 & 3139 \\
\hline
\end{tabular}

After the analysis of the 'test set', in 154 (Figure 4) of the sites, a $\mathrm{H}_{\mathrm{ava}}$ higher than that required for a 2-KW MHP installation was found. These sites with potential presented the $H_{\min }$ required with maximum values ranging between 5 and $13 \mathrm{~m}$, so no cases were found 
where $\mathrm{H}_{\mathrm{ava}}$ was higher than these values in the study area. This also means that generally the available difference in height is relatively small, so there are few cases where small flows result in exploitable power, as only the potential energy is being considered. From these 154 sites with MHP potential, more than half (62\%) corresponded to Municipal WWTPs. This time, the distribution among the different river basins showed Ebro as the one with more sites, accounting for a total of 52 (34\% of the total sites with potential), despite not being one of the basins with the largest population but with a larger total area, with the highest number of industries and fish farms with MHP potential. Behind the Ebro basin, the Tajo river basin, with $30 \%$ of the sites, among which the contribution of WWTPs stands out, as expected, was the basin with the largest population of the set. The rest of sites were distributed between the Jucar, Duero, Guadalquivir and Guadiana river basin areas, with $14 \%, 13 \%, 9 \%$ and $1 \%$, respectively. The distribution of sites between the different categories for which MHP potential was above $2 \mathrm{~kW}$ was founded and summarized in Table 2.

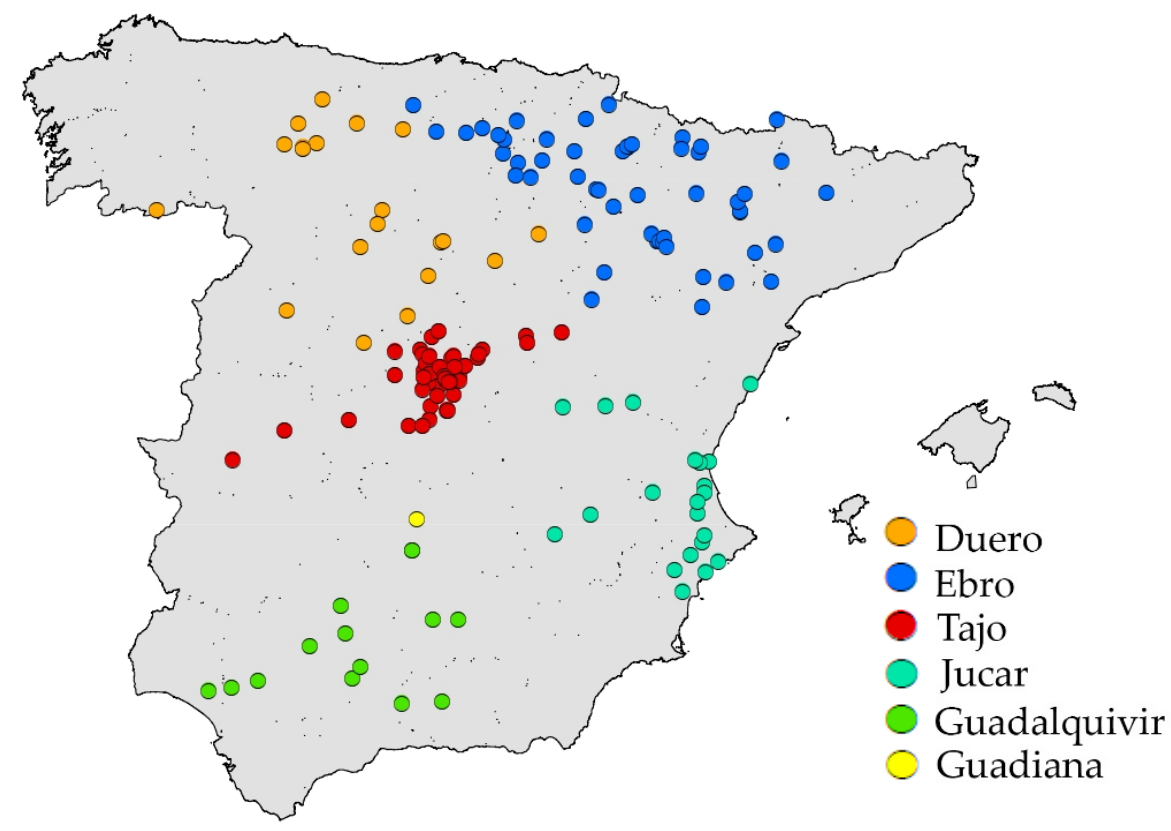

Figure 4. Sites with energy recovery potential for MHP in the 7 rivers basins analysed in Spain.

Regarding the discharge volumes of the sites with potential for MHP, again the Tajo and Ebro river basins showed the highest values, although this time, the Tajo river basin represented 50\% compared with 30\% for the Ebro, considering the total volume. These figures show that although the Ebro river basin gathered more sites with potential, the available volume was $20 \%$ lower than in the case of the Tajo river basin.

\subsubsection{Industry Potential Sites}

The industry category, which represented $18 \%$ of the test set, was divided into six subgroups, based on the activity-agri-food; energy; minerals, metals and construction; paper; chemicals; and others, in which the minority categories were included (such as discharges licenses attributed to tunnels or hotels isolated from the sewage network). Thus, within the industry group, the energy-related industry was the largest subgroup, with 26 sites, followed by the subgroup minerals, metals and construction, with 16 sites and, matched in number (12 sites), the agri-food industry and the subgroup "others". From the 'test set', a total of 35 industries showed any MHP potential above $2 \mathrm{~kW}$, representing $23 \%$ of the total identified sites with potential. The Ebro river basin was the area with more industries with potential, accounting a total of 19 sites (54\% of industries with potential), followed by the Duero with six and Tajo with five. 


\subsubsection{Fish Farms Potential Sites}

Fish farms represented $9 \%$ of the initial 'test set'. Their representation in the different river basins showed a prevalence in the Duero and Ebro basins, covering the northern part of the country, with $74 \%$ of the listed fish farms. These were not present in any of the cases of the Guadiana and Segura river basins that met the head and power conditions imposed. Related to the sites with power potential higher than $2 \mathrm{~kW}$, a total of 24 fish farms with potential were found, principally located in the Ebro river basin, with 14 being in this area.

\subsubsection{Municipal WWTPs Potential Sites}

The Municipal WWTPs were the type of facility that had the greatest presence in the 471 listed sites for the evaluation of energy recovery potential for MHP, representing 73\% of the total identified sites. WWTP was also the type of facility which presented more sites with potential for all river basins except in the case of the Ebro river, in which both WWTPs and industry presented the same quantity (19 sites). At the country level, WWTPs showed the most numerous group, with 95 sites, representing more than $62 \%$ of the total sites with MHP potential.

\subsection{Power Estimations and Energy Recovery Potential Assessment}

The power and energy potential estimations were calculated assuming an average annual flow for all facilities, based on the annual discharge volume detailed in the corresponding discharge licenses, and considering an overall efficiency of 0.6 for the MHP installation. The total power potential was estimated as $3.31 \mathrm{MW}$, for which $50.6 \%, 13.8 \%$ and $35.6 \%$ corresponded to the industry, fish farms and Municipal WWTPs, respectively. From the total 154 sites with power potential for MHP above $2 \mathrm{~kW}, 39$ sites exceeded 15 $\mathrm{kW}$ of power (13 in industry sector, eight fish farms and 18 Municipal WWTPs) (Figure 5). The distribution and percentages for areas and categories followed the same pattern for the potential energy production, due to the fact that the same working time was assumed for all facilities. The total energy generation reached $29 \mathrm{GWh} \cdot \mathrm{year}^{-1}$, from which $80 \%$ corresponded to sites with power potential over $15 \mathrm{~kW}$. The percentage breakdown of energy potential generation for the different categories in each river basin is detailed in Figure 6 .

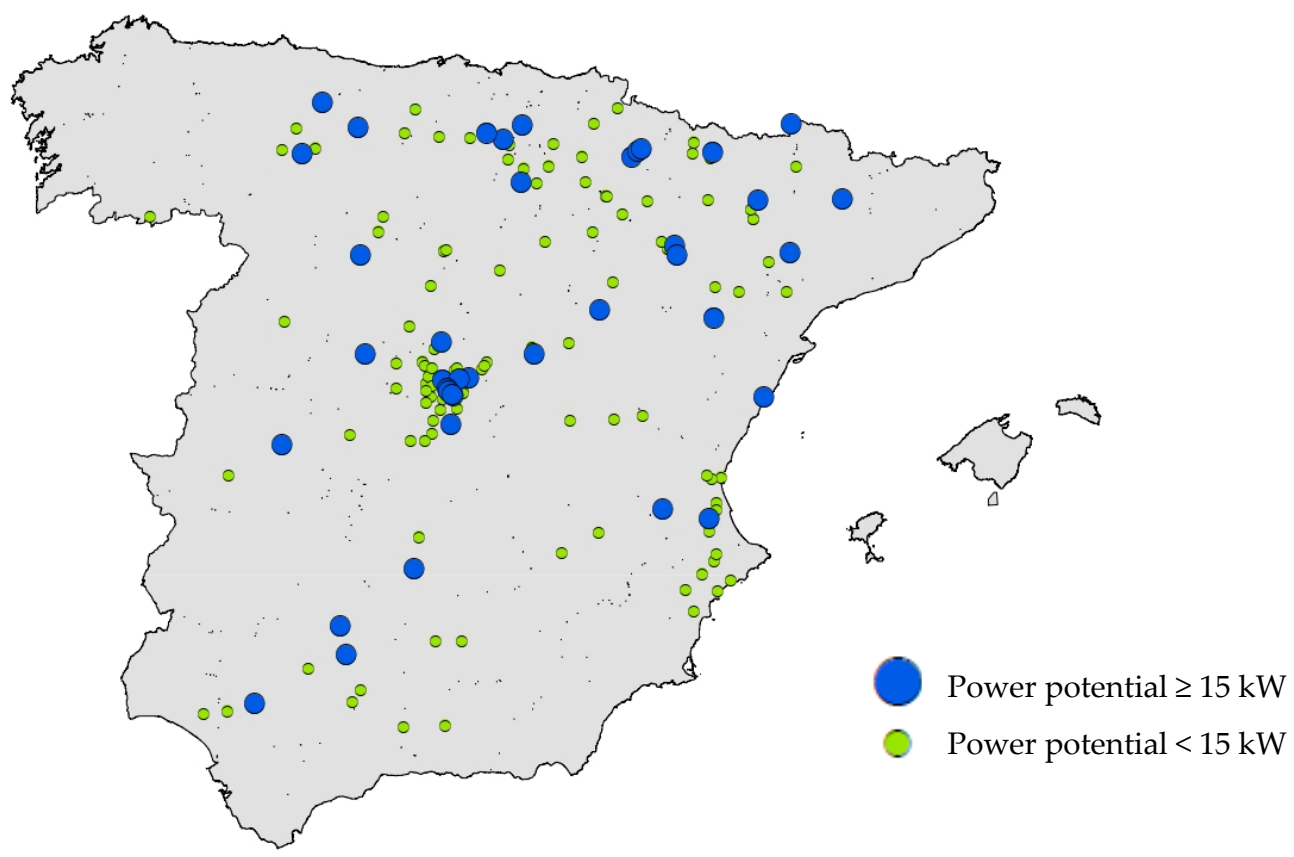

Figure 5. Geographic distribution of sites with potential up to and above $15 \mathrm{~kW}$ for the different river basins in Spain. 


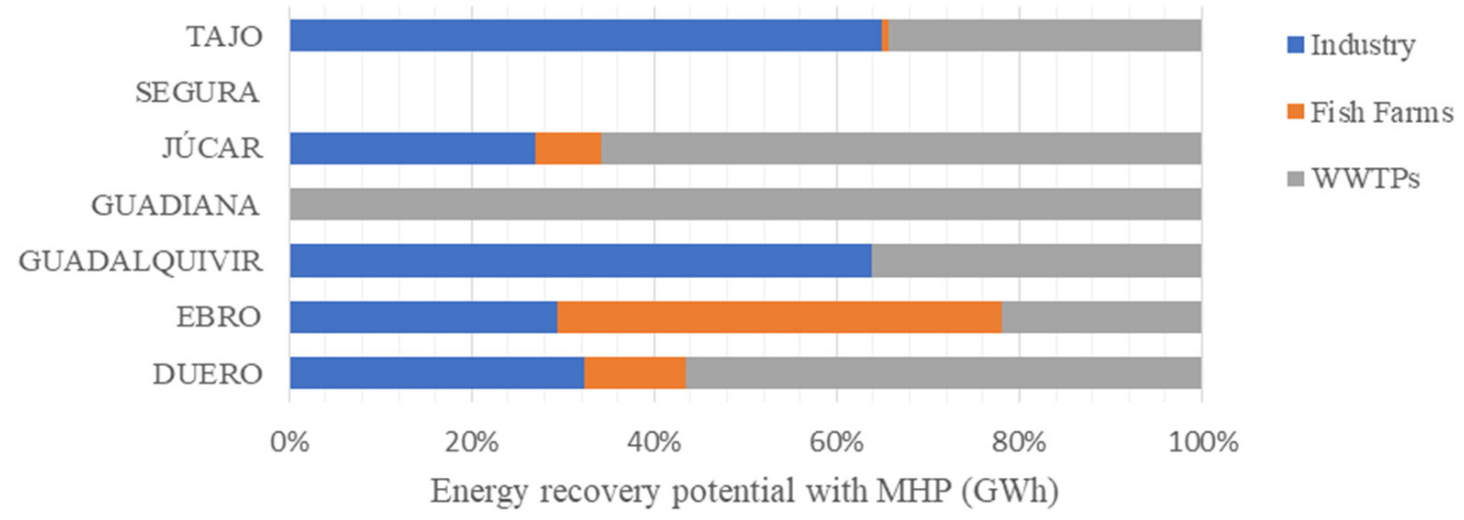

Figure 6. Percentage distribution of the potential energy generation with MHP in the different sectors for the seven river basins analysed.

Figure 7 summarizes the sites, power and energy potential estimations and its distribution between sectors.

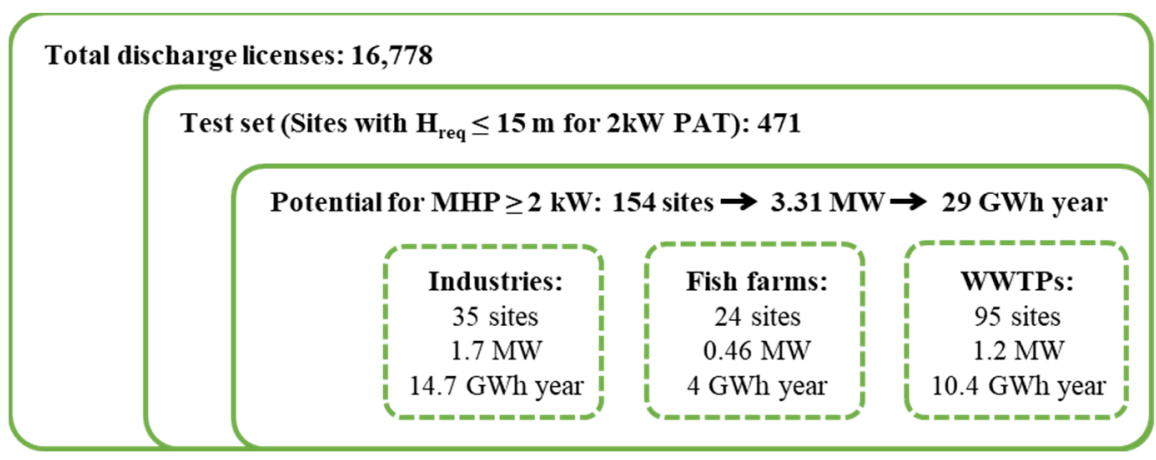

Figure 7. Synthesis of the results obtained in terms of number of sites with MHP potential, and power and energy estimations for the different sectors.

As shown in Figure 7, although industries presented a lower number of sites with MHP potential compared to the WWTPs, the higher volume of water per site resulted in a higher potential in terms of energy generation, and a higher productivity. Thus, the highest ratio of energy production per site corresponded to the private industry, more than two and almost three times higher than the ratio obtained for the fish farms and the WWTPs, respectively.

\subsubsection{Industry Energy Recovery Potential}

In a general overview, most of the industries presented restrictions for MHP production due to low flow values. The highest contribution in the industry group, which represented 1.7 MW of power potential for MHP, corresponded to the energy-related industries, amounting to $45 \%$ of the total power potential for Spain. From this $45 \%, 70 \%$ (equal to $1492 \mathrm{~kW}$ ) came from the Tajo river basin, with two nuclear power plants. After energy-related industries, the following subgroup within the industry category was the paper industry, which contributed with $70.7 \mathrm{~kW}$ of power, most of these coming from the Ebro river basin. Thus, the industry sector represented an annual energy recovery potential of $14.7 \mathrm{GWh}$, which was half of the total. Table 3 shows the breakdown for the energy recovery contribution of the different subgroups of industries in the river basins analysed. 
Table 3. Annual energy recovery potential in MWh for the different industry sub-groups and river basins analysed in Spain.

\begin{tabular}{ccccccc}
\hline & Agri-Food & Energy & $\begin{array}{c}\text { Minerals, Metals } \\
\text { and Construction }\end{array}$ & Paper & Chemicals & Others \\
\hline Duero & 36.98 & 816.21 & 28.11 & 56.41 & 33.39 & - \\
Ebro & - & 866.34 & 333.08 & 536.06 & 357.11 & - \\
Guadalquivir & - & 1811.31 & - & 27.21 & 18.89 & - \\
Guadiana & - & - & - & - & - & - \\
Júcar & - & 394.29 & - & - & - & - \\
Segura & - & - & - & - & 151.35 & - \\
Tajo & 32.16 & 9182.48 & 361.19 & 619.68 & 560.74 & - \\
Total & 69.14 & $13,070.62$ & & &
\end{tabular}

Although the literature review has shown, in general terms, that the energy recovery potential through MHP has been rarely addressed in the industry sector, these results point to a positive contribution to the clean energy generation by MHP, especially in some specific industries such as the energy production-related ones.

\subsubsection{Fish Farms Energy Recovery Potential}

Fish farms presented a total power potential estimation of $0.46 \mathrm{MW}$, representing $14 \%$ of the total power potential. As it was previously detailed in Section 3.1.2, from the 42 possible fish farms included in the 'test set', only 24 of them resulted in any potential for MHP. In many cases, the proximity of the installation to the riverbed made the availability of head too low, even though the flow conditions would allow, given its continuity and volume, to install a PAT or other micro-turbine. Most of the power potential found corresponded to the Ebro river basin, which accounted for $87 \%$ of the power potential estimated for this category. Table 4 presents the distribution of the annual energy potential estimated for the fish farm sector in the different river basins and its associated water volume, including the ratio between them. This ratio shows the difference between river basins in the conversion of water volume into energy due to the head available in the different sites. Thus, the Ebro river basin showed the highest value for this ratio, with $0.028 \mathrm{GWh} \mathrm{Hm}^{-3}$ while the Tajo river presented the lowest value, with $0.0005 \mathrm{GWh} \mathrm{Hm}^{-3}$.

Table 4. Energy potential for MHP and the corresponding annual volume of water breakdown for the fish farm sector in the different river basins.

\begin{tabular}{cccc}
\hline & Energy $\mathbf{( G W h )}$ & Volume $\mathbf{( H m}^{\mathbf{3}} \mathbf{)}$ & Energy/Volumen Ratio \\
\hline Duero & 0.3 & 46 & 0.0065 \\
Ebro & 3.5 & 125 & 0.0280 \\
Guadalquivir & - & - & - \\
Guadiana & - & - & - \\
Jucar & 0.1 & 63 & 0.0015 \\
Segura & - & - & - \\
Tajo & 0.1 & 192 & 0.0005 \\
Total/mean & 4.0 & 426 & 0.0094 \\
\hline
\end{tabular}

This analysis of the fish farms points to a generalized lack of a head drop in many cases, which hinders the exploitation of the MHP potential of the effluent flow. Even though no previous studies focusing on the MHP potential assessment in fish farms have been found, the potential of this technology in rivers has been previously addressed. Thus, one of the highlighted challenges in such off-grid cases is that the use of the recovered energy should be placed in the vicinity of the MHP plant, as its transport to other locations would require important investments in infrastructure [26]. 


\subsubsection{Municipal WWTPs Energy Recovery Potential}

In the case of the Municipal WWTPs, the total power potential amounted to $1.2 \mathrm{MW}$. The Tajo river basin was the area with the highest contribution, representing $0.6 \mathrm{MW}$, followed by the Duero, with $0.2 \mathrm{MW}$ of power potential. In this case, the higher power potential related to the Municipal WWTP in the Tajo basin could be associated with the higher population, which amounted to $7.88 \mathrm{M}$ people, representing $30 \%$ of the total population associated with the seven river basins. In terms of energy, the total potential was estimated at $10.35 \mathrm{GWh} \cdot$ year $^{-1}$, and its distribution between river basins and the corresponding discharge volume are summarized in Table 5.

Table 5. Energy potential for MHP and the corresponding annual volume of water and population breakdown for the WWTP sector in the different river basins.

\begin{tabular}{cccc}
\hline & Energy (GWh) & Volume $\left(\mathbf{H m}^{3}\right)$ & $\begin{array}{c}\text { Energy/Population Ratio } \\
\text { (GWh Per Person and Year) }\end{array}$ \\
\hline Duero & 1.7 & 30 & 0.77 \\
Ebro & 1.6 & 54 & 0.49 \\
Guadalquivir & 1.1 & 77 & 0.26 \\
Guadiana & 0.12 & 6 & 0.08 \\
Jucar & 1.0 & 95 & 0.19 \\
Segura & - & - & - \\
Tajo & 4.9 & 579 & 0.63 \\
Total & 10.4 & 842 & 0.40 \\
\hline
\end{tabular}

The ratio between the energy potential and total population of the river basin showed the differences between the six river basins for which any potential was found, as previously suggested by Bousquet et al. [24]. The Duero river basin showed the highest value, with $0.77 \mathrm{kWh}$ of energy per person, against the 0.08 obtained for Guadiana basin, which presented the lowest value, the average for the country being 0.40 . These differences were due to several factors, such as the covered area and population, which conditioned the number of WWTPs and corresponding wastewater volumes, or the topography. In this way, the Duero basin presented initially 5816 licenses and $861 \mathrm{Hm}^{3}$ against 565 licenses and $105 \mathrm{Hm}^{3}$ of the Guadiana basin.

\subsection{Economical and Greenhouse Gas Emissions Savings Projection}

Considering the total energy recovery potential for MHP estimated for the seven river basins in Spain, the sum for the three sectors reached an annual total of $29 \mathrm{GWh}$. Assuming an average conversion factor of $0.357 \mathrm{~kg} \mathrm{CO}_{2}$ eq. per $\mathrm{kWh}$ of electricity coming from the electricity grid in Spain [7], the estimated total energy production represented a saving of around 11,353 tonnes $\mathrm{CO}_{2}$ eq. Moreover, in economic terms, the potential energy generated by MHP in the industry, Municipal WWTPs and fish farms would represent an annual reduction between $\mathrm{M} € 2.11$ and $\mathrm{M} €$ 4.24, for an average cost of electricity in peak and valley periods.

\subsection{Sensitivity Analysis}

Once the total MHP energy generation potential in Spain was assessed, the possible variation in results when considering a shorter operating time of the facilities was evaluated. Thus, the assessment of the possible sites with MHP potential under a $12 \mathrm{~h}$-day operating pattern was carried out for the total of discharge licenses included in the initial database. The new criteria doubled the power to be installed in those sites that already showed any MHP potential in the first assessment, as the flow rate is doubled. This higher power, combined with the $50 \%$ reduction in the operating time, resulted in the annual potential for energy generation remaining unchanged. However, the 12-h working assumption included 348 new discharge licenses to be analysed, increasing the initial test set by $74 \%$. From those, only 21 sites showed any potential for MHP higher than $2 \mathrm{~kW}$, as the rest 
did not have the required difference in height. The WWTPs and industries related with the energy production represented 14 and one of these sites, respectively. In both cases, a 12-h operating regime was considered less realistic than 24-h working time, so finally, only six new sites (five from the agri-food sector and one from the construction sector) were included in the final calculations. The inclusion of these six industries supposed an increase of $22 \mathrm{~kW}$ of power, equal to an annual energy generation potential of $98 \mathrm{MWh}$, which represented only a $0.3 \%$ increase.

\section{Conclusions}

An assessment of the power and energy potential for MHP in the municipal wastewater, industry and fish farm sectors was addressed for the Spanish area, estimating a total potential power between 3.31 and $3.54 \mathrm{MW}$ and an annual energy recovery potential of $29 \mathrm{GWh}$. The operating time variation between 12 and $24 \mathrm{~h}$ in the private industry sector did not represent significant changes in the total results, increasing the annual energy potential generation by only $0.3 \%$. Previous investigations of MHP potential in wastewater systems have not included industrial treatment plants from water-intensive industry. Yet, these have been shown to account for $50.9 \%$ of the total potential here, a finding which could greatly influence MHP potential estimates across the world. It also identifies a significant new avenue for the exploitation of multipurpose MHP technology. Obviously, more detailed information on the operating regime and flow rates of the analysed installations would allow much more accurate results to be obtained.

The results here corresponded to the seven river basins analysed in Spain, which included the Duero, Ebro, Guadalquivir, Guadiana, Jucar, Segura and Tajo rivers, covering $78 \%$ of the country total area and $80 \%$ of the peninsular Spanish area. The distribution between river basins was irregular, showing either no or a very low potential for MHP in basins such as the Segura and Guadiana, respectively. The estimated energy potential represented a potential $\mathrm{CO}_{2}$ emission savings of around 11 thousand tonnes, which represented a reduction between $\mathrm{M} € 2.11$ and $\mathrm{M} € 4.24$ in the total energy consumption in the country. These figures show only an approximation, since the available data corresponded to maximum annual authorised discharge volumes, which was considered to be distributed over the 365 days of the year, and 24/12 h of work per day. However, the possibility of having access to flow records in real time or hourly, could facilitate a more detailed study by sector, and even by type of industry. The analysis of this country-level data shows the potential interest in the use of MHP technology for clean energy generation in the wastewater, industry and fish farm sectors, whose results and conclusions could be extrapolated to other countries. The subsequent use of the energy produced would require the analysis of the possibilities of usage at the point of generation, in some cases, or the injection into the grid. The last one could present some difficulties in certain isolated areas, as it can be the case of most of the fish farms. However, the robustness and low cost of the technology for these small hydropower plants opens a way to reduce greenhouse gas emissions linked to electricity production as well as to improve energy efficiency in the sectors addressed. This fact becomes even stronger when most of the estimated MHP potential is concentrated in sites with more than $15 \mathrm{~kW}$ of power. This shows that a large part of this energy generation potential, in this case $80 \%$, could be exploited by installing MHP plants in a small number of sites.

Of course, this work represents a preliminary assessment of the potential applicability of MHP technology as an added-value resource to contribute to the transformation of the industrial and wastewater sectors into more sustainable activities, at a country level. Future research should be directed towards in-site detailed assessments in the different sectors, which could help to understand the advantages and drawbacks linked to MHP energy recovery in each specific industrial sector.

Author Contributions: Conceptualization, J.A.R.D., J.G.M. and A.M.; methodology, A.M.G. and A.M.; formal analysis, A.M.G. and A.M.; investigation, A.M.G. and A.M.; resources, A.M.G.; writing- 
original draft preparation, A.M.G.; writing-review and editing, J.A.R.D., J.G.M. and A.M.; supervision, A.M. All authors have read and agreed to the published version of the manuscript.

Funding: This research is part funded by the European Regional Development Fund (ERDF) through the Interreg Atlantic Area Programme 2014-2020, as part of the REDAWN project (Reducing the Energy Dependency in the Atlantic Area from Water Networks).

Institutional Review Board Statement: Not applicable.

Informed Consent Statement: Not applicable.

Data Availability Statement: Not applicable.

Conflicts of Interest: The authors declare no conflict of interest.

\section{References}

1. Morani, M.C.; Carravetta, A.; Del Giudice, G.; McNabola, A.; Fecarotta, O. A comparison of energy recovery by PATs against direct variable speed pumping in water distribution networks. Fluids 2018, 3, 41. [CrossRef]

2. IEA. Global Energy \& $\mathrm{CO}_{2}$ Status Report. 2019. Available online: https: / / www.iea.org (accessed on 10 September 2020).

3. Hoekstra, A.Y. The Water Footprint of Industry. In Assessing and Measuring Environmental Impact and Sustainability; ButterworthHeinemann: Oxford, UK, 2015; pp. 221-254. ISBN 9780128022337. [CrossRef]

4. UNESCO. Programa Mundial de Evaluación de los Recursos Hídricos (WWAP). Available online: http://www.unesco.org (accessed on 27 February 2020).

5. Gerbens-Leenes, P.W.; Mekonnen, M.M.; Hoekstra, A.Y. The water footprint of poultry, pork and beef: A comparative study in different countries and production systems. Water Resour. Ind. 2013, 1-2, 25-36. [CrossRef]

6. EEA. Final Energy Consumption by Sector and Fuel in Europe; Statistical Office of the European Union (Eurostat), European Environment Agency: Copenhagen, Denmark, 2020; p. 20.

7. Ministerio de Industria, Energía y Turismo. Factores de Emisión de $\mathrm{CO}_{2}$ y Coeficientes de Paso a Energía Primaria de Diferentes Fuentes de Energía Final Consumidas en el Sector de Edificios en España; Documento Reconocido del Reglamento de Instalaciones Térmicas en los Edificios (RITE): Barcelona, Spain, 2016. [CrossRef]

8. McNabola, A.; Coughlan, P.; Corcoran, L.; Power, C.; Williams, A.P.; Harris, I.; Gallagher, J.; Styles, D. Energy recovery in the water industry using micro-hydropower: An opportunity to improve sustainability. Water Policy 2014, 16, 168-183. [CrossRef]

9. Cabrera, E.; Pardo, M.A.; Cobacho, R.; Cabrera, E. Energy Audit of Water Networks. J. Water Resour. Plan. Manag. 2010, 136, 669-677. [CrossRef]

10. Ramos, H.M.; Mello, M.; De, P.K. Clean power in water supply systems as a sustainable solution: From planning to practical implementation. Water Sci. Technol. Water Supply 2010, 10, 39-49. [CrossRef]

11. Filion, Y.R.; MacLean, H.L.; Karney, B.W. Life-Cycle Energy Analysis of a Water Distribution System. J. Infrastruct. Syst. 2004, 10, 120-130. [CrossRef]

12. Chae, K.J.; Kim, I.S.; Ren, X.; Cheon, K.H. Reliable energy recovery in an existing municipal wastewater treatment plant with a flow-variable micro-hydropower system. Energy Convers. Manag. 2015, 101, 681-688. [CrossRef]

13. Gallagher, J.; Harris, I.M.; Packwood, A.J.; McNabola, A.; Williams, A.P. A strategic assessment of micro-hydropower in the UK and Irish water industry: Identifying technical and economic constraints. Renew. Energy 2015, 81, 808-815. [CrossRef]

14. Corcoran, L.; McNabola, A.; Coughlan, P. Optimization of water distribution networks for combined hydropower energy recovery and leakage reduction. J. Water Resour. Plan. Manag. 2016, 142, 1-8. [CrossRef]

15. McNabola, A.; Coughlan, P.; Williams, A.P. The technical \& economic feasibility of energy recovery in water supply networks. Renew. Energy Power Qual. J. 2011, 1, 1123-1127. [CrossRef]

16. Power, C.; McNabola, A.; Coughlan, P. Development of an evaluation method for hydropower energy recovery in wastewater treatment plants: Case studies in Ireland and the UK. Sustain. Energy Technol. Assess. 2014, 7, 166-177. [CrossRef]

17. Griffin, F.M. Feasibility of energy recovery from a wastewater treatment scheme. Proc. Inst. Mech. Eng. Part A J. Power Energy 2000, 214, 41-51. [CrossRef]

18. Pérez-Sánchez, M.; Sánchez-Romero, F.J.; Ramos, H.M.; López-Jiménez, P.A. Optimization strategy for improving the energy efficiency of irrigation systems by micro hydropower: Practical application. Water 2017, 9, 799. [CrossRef]

19. Crespo Chacón, M.; Rodriguez Díaz, J.A.; García Morillo, J.; McNabola, A. Pump-as-turbine selection methodology for energy recovery in irrigation networks: Minimising the payback period. Water 2019, 11, 149. [CrossRef]

20. García Morillo, J.; McNabola, A.; Camacho, E.; Montesinos, P.; Rodríguez Díaz, J.A. Hydro-power energy recovery in pressurized irrigation networks: A case study of an Irrigation District in the South of Spain. Agric. Water Manag. 2018, 204, 17-27. [CrossRef]

21. Fecarotta, O.; Ramos, H.M.; Derakhshan, S.; Del Giudice, G.; Carravetta, A. Fine Tuning a PAT Hydropower Plant in a Water Supply Network to Improve System Effectiveness. J. Water Resour. Plan. Manag. 2018, 144, 04018038. [CrossRef]

22. Da Silva, B.L.A.; Lafay, J.M.S.; Tofoli, F.L.; Scartazzini, L.S. Case study: Hydroelectric generation employing the water distribution network in Pato Branco, Brazil. Proc. IASTED Int. Conf. Power Energy Syst. Eur. 2011, 2011, 50-54. [CrossRef] 
23. Fecarotta, O.; McNabola, A. Optimal Location of Pump as Turbines (PATs) in Water Distribution Networks to Recover Energy and Reduce Leakage. Water Resour. Manag. 2017, 31, 5043-5059. [CrossRef]

24. Bousquet, C.; Samora, I.; Manso, P.; Rossi, L.; Heller, P.; Schleiss, A.J. Assessment of hydropower potential in wastewater systems and application to Switzerland. Renew. Energy 2017, 113, 64-73. [CrossRef]

25. Novara, D.; Carravetta, A.; McNabola, A.; Ramos, H.M. Cost Model for Pumps as Turbines in Run-of-River and In-Pipe Microhydropower Applications. J. Water Resour. Plan. Manag. 2019, 145, 1-9. [CrossRef]

26. Fujii, M.; Tanabe, S.; Yamada, M.; Mishima, T.; Sawadate, T.; Ohsawa, S. Assessment of the potential for developing mini/micro hydropower: A case study in Beppu City, Japan. J. Hydrol. Reg. Stud. 2017, 11, 107-116. [CrossRef] 